\title{
FEATURE Targeting riparian buffers and grassed waterways to address freshwater species decline
}

\author{
Clayton Ogg and Michelle Perez
}

$\mathbf{T}$ argeting conservation practices greatly increases economic efficiency (1) if the resource problem occurs primarily within a small geographic area and (2) if the conservation practice is targeted within the area where it works most effectively. Over $73 \%$ of United States' freshwater mussel species, $35 \%$ of amphibians, and $37 \%$ of fish have been classified as vulnerable, imperiled, or endangered (Henley et al. 2000; Williams et al. 1993). These species' problems are concentrated in certain Southeastern streams and rivers, where an estimated (Neves et al. 1997) 91\% of the United States' freshwater mussels, 53\% of fingernail clams, and $61 \%$ of snails reside. For rare mussel species most in need of protection, $98 \%$ of these species occur in the Southeast (Neves et al. 1997).

Much of the above destruction and decline of aquatic species stems from industrial pollution, stream alteration due to impoundment and channel modification, invasive species, and sedimentation (Henley et al. 2000; Neves et al. 1997). Sediment pollution from nonpoint sources remains as the largest, unaddressed problem in the above southeastern streams since urban and industrial point sources of pollution have been addressed to a substantial degree under the 1977 Clean Water Act (Neves et al. 1997). It is useful to document in more detail where sediment pollution is a major driver for the decline and loss of aquatic species and where it is not.

Several important sediment-reducing practices for farmland sources of soil erosion, such as riparian buffers and grassed waterways (filter strips), are available for technical and financial assistance by USDA and by their joint programs with states. These practices can reduce sedimentation by nearly $50 \%$ (Gassman et al. 2009; Tuppad

Clayton Ogg is director of Conservation Economics and Finance, Defenders of Wildlife, Washington, DC. Michelle Perez is senior associate with the Water Quality Team, World Resources Institute, Washington, DC.

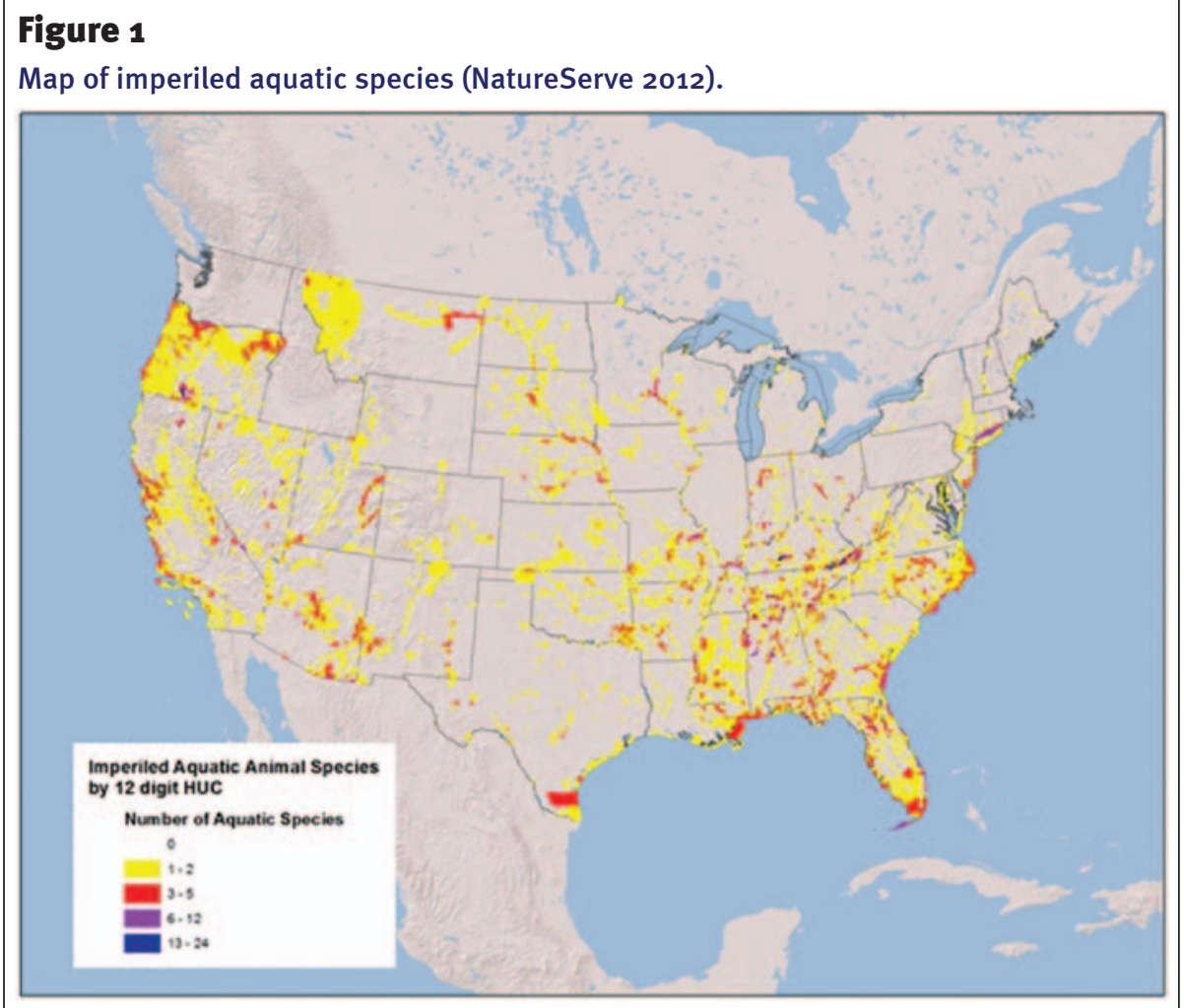

et al. 2010). Although southeastern states exploit USDA's Conservation Reserve Program (CRP) and their Conservation Reserve Enhancement Program (CREP) agreements with USDA to address biodiversity challenges, more buffer and grassed waterway targeting opportunities remain. Programs can be designed to target buffer incentives to streams with large numbers of vulnerable aquatic species and to locations where buffers are most effective in reducing sedimentation and in supporting freshwater species that benefit from riparian habitats.

\section{SOUTHEASTERN AQUATIC SPECIES VULNERABILITY TO SEDIMENT}

Excessive sedimentation takes place in $34 \%$ of US streams and rivers and is considered the most important limitation regarding fish habitat (Judy et al. 1984; Henley et al. 2000). In a national survey of fisheries biologists, turbidity, largely from agriculture (Richter et al. 1997), was considered the most harmful of aquatic pollutants. For the more than 120 listed streams, all but a handful of US Fish and Wildlife Service (USFWS 2012) recovery plans call for actions to reduce agricultural sediment and/or to restore habitat adjacent to the stream. (These recovery plans can be found on the US Fish and Wildlife Service website that was last updated in 2012 [USFWS 2012].)

Mussels are especially vulnerable to sediment pollution in streams because mussels generally depend on specific host fish species in order to reproduce. If either the mussel or the host fish is susceptible to a pollutant, such as sediment, then the mussel potentially faces serious difficulty (Neves et al. 1997). Mussel varieties differ in their ability to tolerate siltation in streams. Some species, such as the yellow sandshell, experienced substantial mortality from just $2.5 \mathrm{~cm}$ (0.98 in) of deposited silt (Ellis 1936; Henley et al. 2000). Certain other mussel species experienced very widespread mortality only when exposed to $45 \mathrm{~cm}$ (17.7 in) of silt (Imlay 1972). aquatic species in southeastern rivers and 
Fish also vary widely in their ability to tolerate turbidity and siltation. One study (Burkhead and Jelks 2001) found that 20\% fewer eggs were laid by the tricolor shiner of the Mobile River because of increased sedimentation that was measured in the study, while other fish species were even more vulnerable. Suspended sediment also negatively affects fish food sources, such as algae (Henley et al. 2000). In addition, loss of insect populations from even small amounts of sediment deposition can negatively affect aquatic species that consume them.

\section{BENEFITS FROM TARGETING CONSERVATION RESERVE PROGRAM TO PROTECT VULNERABLE AQUATIC SPECIES}

Sediment pollution is both the most pervasive pollution problem in the United States and the major problem that received the least protection under the Clean Water Act (Neves et al. 1997). However, the CRP and Conservation Compliance Program, which were created by 1985 farm legislation to target soil erosion on the small portion of US cropland that erodes at the highest rates (Hansen and Claasen 2001), contributed nationally to a $40 \%$ reduction in soil erosion from US cropland.

Among southeastern states, Mississippi and Alabama have the largest enrollment in CRP's general sign-up, with 10.9\% and $9.9 \%$ of the respective states' cropland enrolled (table 1). Soil erosion reductions achieved by these CRP enrollments of whole fields of highly erodible land in Mississippi and Alabama are large, aver- aging 44 and $38 \mathrm{t} \mathrm{ha}^{-1} \mathrm{y}^{-1}$ (20 and $17 \mathrm{tn}$ $\left.\mathrm{ac}^{-1} \mathrm{yr}^{-1}\right)$. Although CRP enrollments are declining due to high crop prices and tight budgets, continued support for these CRP general sign-up practices on the most erodible land is crucial for aquatic species.

Although buffer performance varies a lot depending on local conditions, buffers and grassed waterways offer a similarly powerful targeting tool, like the above CRP general sign-up programs for highly erodible land, because buffer practices enroll only a small portion of cropped fields $(1 \%-2 \%)$ adjacent to streams and waterways but can reduce sediment runoff by nearly half (Gassman et al. 2009; Tuppad et al. 2010). In addition, riparian buffers and grassed waterways reduce herbicide (Hall et al. 1983) and nutrient delivery (Haycock and Pinay 1993) to streams from cropped fields by as much as $80 \%$ and $90 \%$, respectively.

\section{MULTIPLE BENEFITS FROM RIPARIAN BUFFERS}

In response to a 2010 listing petition from the Center for Biological Diversity and other groups, the US Fish and Wildlife Service found in September 2011 that protection of 374 freshwater species in 12 southeastern states may be warranted under the Endangered Species Act, including plants, amphibians, birds, insects, and other creatures that inhabit adjacent riparian areas as well as aquatic species (USFWS 2011). Many of these creatures reside in riparian areas of the southeastern United States, as well as in the streams themselves, and over half of the 374 petitioned spe- cies are affected primarily by agriculture (Center for Biological Diversity 2010).

These species could benefit greatly from the above CRP erosion reductions and from its riparian buffer establishment. In southeastern states, buffers provide bottomland hardwood habitat adjacent to the streams, which is especially beneficial to freshwater species that reside next to streams. In many cases, the species that benefit from more riparian habitat are located only on certain stream reaches which could be targeted. Aquatic species within the stream itself benefit directly from the improved stream habitat that often results from riparian buffers (Henley et al. 2000; Whitworth and Martin 1990), as well as from the reductions in sediment disposition and turbidity that riparian buffers and grassed waterways can provide. In addition, buffers may reduce nitrate loadings in streams even more than they reduce sediment (Haycock and Pinay 1993). Nitrate is a major cause of sea grass loss and other problems affecting species that reside in coastal estuaries (Peterson et al. 2011).

Most of the land adjacent to southeastern streams is already forested, and cropland is relatively inexpensive. This makes targeting the remaining cropped area adjacent to streams, or next to intermittent streams, with respective riparian buffers or grassed waterways a cost-effective option.

\section{PAST USE OF CONSERVATION RESERVE PROGRAM BUFFERS IN SOUTHEASTERN STATES}

Conservation Reserve Enhancement Program collaborations between USDA

\section{Table 1}

Selected Conservation Reserve Program practices (in thousands of acres) in certain southeastern states and in the United States (USDA FSA 2012).

\begin{tabular}{|c|c|c|c|c|c|c|c|c|c|c|c|}
\hline Practices & MS & AL & AR & sc & NC & LA & GA & TN & $\mathbf{F L}$ & KY & US \\
\hline General sign-up & 606 & 310 & 116 & 98 & 55 & 192 & 219 & 161 & 51 & 171 & 24,335 \\
\hline Filter strip, CP21 & 8 & 1 & 6 & 4 & 3 & 1 & 0 & 9 & 0 & 29 & 983 \\
\hline Riparian buffer, CP22 & 171 & 34 & 62 & 26 & 31 & 5 & 1 & 6 & 0 & 25 & 877 \\
\hline
\end{tabular}

Notes: $\mathrm{MS}=$ Mississippi. $\mathrm{AL}=$ Alabama. $\mathrm{AR}=$ Arizona. $\mathrm{SC}=$ South Carolina. $\mathrm{NC}=$ North Carolina. $\mathrm{LA}=\mathrm{Louisiana} . \mathrm{GA}=\mathrm{Georgia} . \mathrm{TN}=\mathrm{Tennessee} . \mathrm{FL}=$

Florida. $\mathrm{KY}=$ Kentucky. US = United States. $\mathrm{CP}=$ conservation practice. 
and states generally offer large incentives for riparian buffer and grassed waterway (filter strip) enrollment. These include bonus rental payments that typically are $50 \%$ to $100 \%$ greater than local rental rates for farmland. In the southeastern United States, several states, such as Arkansas, North Carolina, and Kentucky, offer CREPs that focus on riparian buffer enrollment, but other states, such as Tennessee, Georgia, Louisiana, and Florida, do not (USDA FSA 2012).

Though Mississippi has no CREP, it leads the country in riparian buffer enrollments through the CRP's Continuous Sign-up (USDA FSA 2012). The Continuous Sign-up provides between US $\$ 247$ and US $\$ 371 \mathrm{ha}^{-1}$ (US $\$ 100$ to US $\$ 150 \mathrm{ac}^{-1}$ ) bonus payments to farmers at signing and offers a $20 \%$ rental payment bonus beyond local rents, which is a much smaller bonus than those typically provided by CREPs. Table 1 identifies Mississippi's 69,015 ha $(170,539 \mathrm{ac})$ of riparian buffers enrolled in USDA Farm Service Agency's conservation practice 22 (CP22), which accounts for nearly 20\% of total US enrollment of riparian buffers in the CRP under any practice (USDA FSA 2012). Although economists find that economic incentives are important in attracting larger enrollments (Suter et al. 2008), strong administrative support, either from USDA (using Continuous Sign-Up) or from the states (using a CREP), may be a key ingredient to securing the above buffer enrollments by farmers. Riparian buffer enrollments under CREP agreement protect 25,091 ha $(62,000 \mathrm{ac})$ in Arkansas and 12,545 ha $(31,000 \mathrm{ac})$ in North Carolina. Alabama and South Carolina have 13,759 and 10,522 ha (34,000 and 26,000 ac), respectively, of various buffer practices enrolled in CRP through its Continuous Sign-Up.

Although Georgia has not taken advantage of the opportunity to enroll riparian buffers, Georgia enrolled about 80,937 ha $(200,000 \mathrm{ac})$ of longleaf pine (table1), a major restoration of an ecosystem that now occupies less than $7 \%$ of the area that it once dominated (USDA FSA 2012). Louisiana benefits from several of CRP's wetland and hardwood restoration practices, as well as $20,234 \mathrm{ha}(50,000 \mathrm{ac})$ of rare, coastal prairie habitat under a CREP agreement. These two states make considerable use of certain CRP practices that support their vulnerable wildlife, even though they have not yet taken advantage of CRP's riparian buffer and grassed waterway practices.

Creation of the above programs for enrolling buffers and other habitats that are critical to vulnerable freshwater species represents a major accomplishment for USDA Farm Service Administration and for the above states which focus on these opportunities. The buffer practices provide an ongoing opportunity to greatly expand enrollment of buffer habitat.

\section{OTHER CONSERVATION RESERVE PROGRAM TARGETING FOR FRESHWATER SPECIES AND FOR BIODIVERSITY}

Conservation Reserve Program targeting in Mississippi and other southeastern states closely parallels Oregon's and Washington's use of riparian buffers, and the shade they provide, to restore habitat and lower water temperatures for the many vulnerable bull trout, salmon, and other coldwater fish species in those states. Oregon's CREP enrolled about 16,186 ha $(40,000 \mathrm{ac})$ along roughly $4,023 \mathrm{~km}(2,500 \mathrm{mi})$ of streams, while Washington enrolled 9,712 ha $(24,000 \mathrm{ac})$ (USDA FSA 2012). In both states, most of these buffers were applied to rangeland.

In addition to the above focus on buffer enrollments, CRP provides immense wildlife benefits through prairie pothole grassland enrollment of whole fields, which greatly benefits the many species of ducks, shorebirds, and songbirds that are threatened by dramatic changes taking place in this region. Over a third of successful duck nests in the United States are attributable to the CRP (Reynolds et al. 2001). In the past, relatively few of the pothole bird species were included in vulnerable species listings, although for decades these species' decline paralleled loss of grassland and loss of pothole wetlands. However, from 2008 to 2011, the rate of loss of prairie pothole grassland and wetlands greatly increased compared to losses just a few years earlier, such that key prairie pothole counties in eastern
North Dakota and South Dakota lost 10\% to $15 \%$ of their remaining grassland and wetland in this brief 2008 to 2011 period (EWG 2012). These losses are driven by certain crop prices, which have tripled, and by farm program subsidies, which also have tripled in the area (Janssen et al. 2007). If cropland loss rates in the region continue, the most productive area within the prairie pothole region will lose most of its remaining grassland nesting habitat in less than 15 years. It could then see its lists of vulnerable species greatly expand. For example, the US Fish and Wildlife Service identifies about 20 bird species that nest in the prairie pothole region in its list of "Birds of Conservation Concern" (USFWS 2008). This list was developed to help anticipate species that could become listed if conditions continue to deteriorate. More species may join the piping plover on threatened and endangered species lists. Maintaining CRP enrollments in the prairie pothole region, as well as protecting existing prairie grasslands and wetlands, is fast becoming a biodiversity issue.

\section{IMPORTANCE TO CONSERVATION POLICY}

More and more species become listed as threatened and endangered. It may take many years for these species to recover, and costs of protecting even a single species, once it becomes listed, sometimes runs into the hundreds of millions of dollars. Fortunately, stream buffers to reduce sedimentation, targeted to streams where they can most effectively support large numbers of vulnerable aquatic species' recovery, offer a very cost-effective way to benefit large numbers of vulnerable aquatic species. Strategies that focus on riparian buffer establishment efficiently reduce likelihood of new listings and support recovery of species already listed. Southeastern states lead the nation in exploiting CRP's practices aimed at restoring rare ecosystems, but much more could be accomplished to encourage use of its riparian buffer practice.

Conservation programs also achieved success in protecting ducks, shorebirds, and certain other prairie species by providing large areas of nesting habitat and by protecting existing wetlands and grasslands, 
and CRP buffer practices restored salmon habitat in the Northwest. However, improving the status of hundreds of vulnerable freshwater species, and at relatively modest cost, represents an important missed conservation opportunity in several southeastern states, especially Louisiana, Georgia, Tennessee, and Florida. Many organizations support biodiversity recovery and hopefully could become important customers if USDA and/or the above states chose to focus more on restoring important aquatic ecosystems by targeting CRP's riparian buffers and grassed waterway practices.

\section{REFERENCES}

Burkhead, N.M., and H.L. Jelks. 2011. Effects of suspended sediment on the reproductive success of the tricolor shiner, a crevice-spawning minnow. Transactions of the American Fisheries Society 130(5):959-968.

Center for Biological Diversity. 2010. Petition to List 404 Aquatic, Riparian and Wetland Species from the Southeastern United States as Threatened or Endangered under the Endangered Species Act. Washington, DC: Center for Biological Diversity. http://www.biologicaldiversity.org/programs/ biodiversity/1000_species/the_southeast_freshwater_extinction_crisis/pdfs/SE_Petition.pdf.

Ellis, M.M. 1936. Erosion silt as a factor in aquatic environments. Ecology 17:29-42.

EWG (Environmental Working Group). 2012. Unlimited Subsidies, High Prices Threaten "Prairie Potholes". Washington, DC: Environmental Working Group. http://www. ewg.org/agmag/2012/04/subsidized-sodbusting-unlimited-subsidies-high-prices-threaten$\%$ E2\%80\%9Cprairie-potholes\%E2\%80\%9D/.

Gassman, P.W., J.R. Williams, X.Wang, A. Saleh, E. Osei, L.M. Hauck, R.C. Izaurralde, and J.D. Flowers. 2009. The Agricultural Policy Environmental Extender (APEX) model: An Emerging Tool for Landscape and Watershed Environmental Analyses. Center for Agricultural and Rural Development, Technical Report 09-TR 49. Ames, IA: Iowa State University. http://www.card.iastate.edu/publications/synopsis. aspx?id=1101.

Hall,J., N.Hartwig, and L.Hoffman. 1983.Application mode and alternate cropping effects on atrazine losses from a hillside. Journal of Environmental Quality 12: 273-278.
Hansen, L., and R. Claasen. 2001. USDA Conservation Programs: A Look at the Record. Agricultural Outlook. Washington, DC: USDA Economic Research Service. http://www.ers. usda.gov/publications/agoutlook/sep2001/ ao284h.pdf.

Haycock, N., and G. Pinay. 1993. Groundwater nitrate dynamics in grass and poplar vegetated riparian buffer strips during the winter. Journal of Environmental Quality 22:273-278.

Henley, W.F., M.A. Patterson, R.J. Neves, and A.D. Lemly. 2000. Effects of sedimentation and turbidity on lotic food webs: A concise review for natural resource managers. Reviews in Fisheries Science 8:125-139.

Imlay, M.J. 1972. Greater adaptability of freshwater mussels to natural rather than to artificial displacement. Nautilus 86:76-79.

Janssen, L., B. Pflueger, and T. Ahrendt. 2007. Agricultural Land Market Trends: 1991-2007. Brookings, SD: Agricultural Experiment Station, South Dakota State University. http:// ageconsearch.umn.edu/bitstream/9281/1/ ci070272.pdf.

Judy, R.D. Jr., P.N. Seeley, T.M. Murray, S.C. Svirsky, M.R. Whitworth, and L.S. Ischinger. 1984. 1982 National Fisheries Survey. Volume I. Technical report: Initial findings. Report No. FWS/ OBS-84/06. Washington, DC: U.S. Fish and Wildlife Service.

NatureServe. 2012. NatureServe's Central Databases. Arlington,VA: NatureServe. http://www.natureserve.org.

Neves, R.J., A.E. Bogan, J.D. Williams, S.A. Ahlstedt, and P.W.Hartfield. 1997. Status of aquatic mollusks in the Southeastern United States: A downward spiral of diversity. In Aquatic Future in Peril: The Southeastern Perspective, ed. G.W. Benz and D.E. Collins, Special Publication 1. Decatur, GA Southeast Aquatic Research Institute. http://fishwild.vt.edu/mussel/PDFfiles/Status\%20of\%20 Aquatic\%20Mollusks.pdf.

Peterson, C.H., F.C. Coleman, J.B.C. Jackson, R.E.Turner, G.T. Rowe, R.T. Barber, K.A Bjorndal, R.S. Carney, R.K. Cowen, J.M. Hoekstra, J.T. Hollibaugh, S.B. Laska, R.A Luettich Jr., C.W. Osenberg, S.E. Roady, S Senner, J.M. Teal, and P. Wang. 2011. A Once and Future Gulf of Mexico Ecosystem: Restoration Recommendations of an Expert Working Group. Washington, DC: PEW Environment Group. http://www.pewenvironment.org/ uploadedFiles/PEG/Publications/Report/ Petersonetal-GOM-execsummary.pdf.
Reynolds, R., T. Shaffer, R. Renner, W. Newton, and B. Batt. 2001. Impact of the Conservation Reserve Program on Duck Recruitment in the U.S. Prairie Pothole Region. Journal of Wildlife Management 65:765-780.

Richter, B.D., D.P. Braun, M.A. Mendelson, and L.L. Master. 1997. Threats to imperiled freshwater fauna. Conservation Biology 11:1081-1093.

Suter, J., G. Poe, and N. Bills. 2008. Do landowners respond to land retirement incentives? Evidence from the Conservation Reserve Enhancement Program. Land Economics 84(1):17-30.

Tuppad, P., N. Kannan, R. Srinivasan, C.G. Rossi, and J.G. Arnold. 2010. Simulation of agricultural management alternatives for watershed protection. Water Resources Management DOI 10.1007/s11269-010-9598-8. http://ssl.tamu. edu/media/15015/tuppad-2010-simulation $\% 20$ of $\% 20$ agricultural $\% 20$ management $\% 20$ alternatives $\% 20$ for $\% 20$ watershed $\% 20$ protection.pdf.

USDA FSA (Farm Service Agency). 2012. Conservation Reserve Program, Monthly Summary - April, 2012. Washington, DC: USDA Farm Service Agency. http://www.fsa.usda.gov/ Internet/FSA_File/crpstatapr2012.pdf.

USFWS (US Fish and Wildlife Service). 2008. Birds of Conservation Concern 2008. Arlington, VA: US Fish and Wildlife Service Division of Migratory Bird Management. http://www.fws. gov/migratorybirds/.

USFWS. 2011. U.S. Fish and Wildlife Service finds 374 aquatic-dependent species may warrant Endangered Species Act Protection. http://www. fws.gov/southeast/news/2011/11-063.html.

USFWS.2012.Species reports.Listed FWS/Joint FWS and NMFS species and populations with recovery Plans. Washington, DC. http://ecos.fws.gov/ tess_public/TESSWebpageRecovery?sort=1.

Whitworth, M.R., and D.C. Martin. 1990. Instream benefits of CRP filter strips. Transactions of the 55th North American Wildlife Natural Resource Conference 55:41-45.

Williams, J.D., M.L. Warren, Jr., K.S., Cummings, J.L. Harris, and R.J. Neves. 1993. Conservation status of freshwater mussels in the United States and Canada. Fisheries (Bethesda) 18:6-22. 